ISSN 0103-7013

Psicol. Argum., Curitiba, v. 29, n. 66, p. 269-283, jul./set. 2011

Licenciado sob uma Licença Creative Commons

(c) (1) $\$$

\title{
Que voz de criança fala no narcotráfico?
}

\author{
What kind of child's voice speaks in drug trafficking?
}

\begin{abstract}
Ane Ribeiro Patti ${ }^{[a]}$ Lucília Maria Sousa Romão ${ }^{[b]}$
[a] Doutoranda em Psicologia pela Faculdade de Filosofia, Ciências e Letras de Ribeirão Preto da Universidade de São Paulo (FFCLRP/USP), membro do E-L@DIS, Laboratório Discursivo - sujeito, rede eletrônica e sentidos em movimentos (FAPESP), Ribeirão Preto, SP - Brasil, e-mail: anepatti@hotmail.com

[b] Livre docente em Ciência da Informação, profa. Dra. da Graduação em Ciências da Informação e da Documentação e do Programa de Pós-Graduação em Psicologia, ambos da Faculdade de Filosofia, Ciências e Letras de Ribeirão Preto da Universidade de São Paulo (FFCLRP/USP), profa. colaboradora do Mestrado em Ciência, Tecnologia e Sociedade da Universidade Federal de São Carlos (UFSCar). Coordenadora do Grupo de Pesquisa Discurso e Memória: movimentos do sujeito (CNPq) e do E-L@, DIS, Laboratório Discursivo - sujeito, rede eletrônica e sentidos em movimentos (FAPESP), Ribeirão Preto, SP - Brasil, e-mail: luciliamsr@ffclrp.usp.br
\end{abstract}

\author{
"Seja bala, relógio, \\ ou a lâmina colérica, \\ é contudo uma ausência \\ o que esse homem leva" \\ (João Cabral de Melo Neto, Uma faca só \\ lâmina ou Serventia das idéias fixas)
}

\section{Resumo}

Neste trabalho, partimos de um acontecimento escrito - uma dissertação de mestrado - para fazer circular algumas ideias trabalhadas neste pequeno advento de discurso. Selecionamos um capítulo em que investigamos as condições de produção do narcotráfico no país, analisando, à luz da teoria discursiva de Michel Pêcheux (análise do discurso) e da psicanálise de releitura lacaniana, como são/foram produzidos e sustentados sentidos de vida e morte pelos sujeitos-criança inseridos nas tramas do tráfico de drogas. 
Também focamos a heterogeneidade do ser-criança subjetivado nessa formação discursiva própria ao capitalismo. Nosso corpus, constituído por recortes de dados midiáticos (documentário) e científicos (livros e estudos) sobre o tema, aponta para a tensão de efeitos de trabalho no âmbito de algo que (a)firma o sujeito em uma relação imaginária de evidência com seus dizeres, escamoteando outras possibilidades de vir-a-ser. Esses efeitos de evidência são descritos pela análise de discurso como resultantes de uma operação ideológica que naturaliza os sentidos, a ponto de ser naturalizado o paradoxo do "ser criança" um ser filiado aos sentidos característicos do que identificamos que é ser criança. Ao mesmo tempo, são produzidos sentidos de criança que, ao ocupar lugares sociais e funções que estão em oposição ao que é "esperado" de acordo com as leis e estatutos, causam um furo nos sentidos históricos construídos e inscritos socialmente - é essa a condição que caracteriza a criança que convive/trabalha para o narcotráfico, consome drogas e se consome.

Palavras-chave: Análise do discurso. Sujeito. Sentidos de criança. Narcotráfico.

\begin{abstract}
This work elaborates on some of the ideas presented in a master's thesis. We selected a chapter in which we investigated the conditions of the production of illegal drugs in our country, examining, in the light of Michel Pêcheux's discursive theory (discourse analysis) and Lacanian Psychoanalysis, how the senses of life and death are/were produced and sustained by children who are involved in drug trafficking. We also focused on the heterogeneity of "being a child" in this discursive formation common to capitalism. Our corpus, consisting of media and scientific data on the theme (a documentary, books and studies), points to the tension of the effects from work in the context of something that affirms the subject in an imaginary relation of evidence with what he or she says, making other possibilities of coming-to-be disappear. According to a discourse analysis perspective, these effects of evidence are described as the result of an ideological operation that naturalizes the senses, to the extent of naturalizing the paradox of "being a child" - a subject associated to the senses of what it means to be a child. At the same time, new senses of children are produced, which occupy social places and functions that are in opposition to what is "expected" in accordance with the laws and statutes, questioning the historical senses socially constructed and inscribed. This is the condition of the children who live/work with drug trafficking, consuming drugs and consuming themselves.
\end{abstract}

Keywords: Discourse analysis. Subject. Senses of children. Drug trafficking.

\section{Introdução: um pouco das condiçóes de produção do funcionamento do narcotráfico no País}

O artigo que apresentamos agora resulta de uma parte de uma dissertação de mestrado desenvolvida no Programa de Pós-Graduação da Faculdade de Filosofia, Ciências e Letras de Ribeirão Preto da Universidade de São Paulo (FFCLRP/ USP). Nesse trabalho, intitulado "Sentidos e sujeitos discursivos: filhos e netos do narcotráfico no movimento do discurso", pudemos trabalhar o tema mais extensivamente. Ao questionarmos sobre que vOz de criança fala no narcotráfico, evocamos que a criança tem voz, que ela é sujeito, e está inscrita na linguagem e na história, é heterogênea, particular, ainda que muitas vezes ela seja tomada como objeto de gozo do adulto, do discurso capitalista que rege sentidos legitimados em nossa contemporaneidade. Consideramos urgente tanto a rememoração dos sentidos de criança discursivizados até então quanto o posterior estranhamento dessas construções culturais para que possamos efetivar uma crítica e colocar em debate no meio acadêmico as questões que abrangem as "crianças invisíveis" que convivem com o narcotráfico, expostas constantemente a uma violência cotidiana que as submete e com a qual elas naturalizam e/ou não naturalizam, sofrendo com ela e dando a ver o sinto $/ \mathrm{mal}$.

Partimos de uma leitura da análise do discurso (AD) peuchetiana, de matriz francesa, que nos permite fazer uma releitura, no escopo de seu 
quadro teórico-metodológico, de alguns conceitos oriundos da linguística, do materialismo histórico e da psicanálise, para fazer uma incursão sobre como o sujeito-criança se inscreve(u) historicamente nas condições de produção do narcotráfico no Brasil. Da mesma forma, interessa-nos apresentar, ainda que parcialmente, como são essas condições de produção que sustentam o discurso das crianças inseridas no narcotráfico, como surgiu/emergiu/foi possível e naturalizado o tráfico de drogas, marcando algo que, para a teoria discursiva, é fundamental: a exterioridade.

Ao falar em condições de produção, Pêcheux (1990) retoma a exterioridade como constitutiva - ela é parte do texto, da historicidade inscrita nele; é um tipo de memória do dizer que sustenta no já-lá as novas possibilidades de retomadas, e é o ponto de partida para que o analista trabalhe criticamente rumo aos modos de sua relação (do discurso) com a exterioridade, retomando a determinação histórica dos processos de significação, já que ele (analista do discurso) considera que "há uma relação necessária da linguagem com o contexto de sua produção" (Orlandi, 1987, p. 12-13). E isso, que antes era algo externo à linguagem pelo prisma da linguística tradicional, na análise do discurso passa a ser considerado como constitutivo do discurso.

Portanto, a exterioridade se refere tanto ao que fala antes, em outros lugares, em outros tempos, quanto aos dados situacionais ou, em outras palavras, o momento em que o sujeito enuncia em um determinado contexto, em suas condições de produção. O contexto sócio-histórico é o cenário político em que as disputas de sentidos são instaladas (discurso polêmico) e/ou caladas/impostas (discurso autoritário), em que os conflitos constitutivos das relações sociais ora esculpem e ora pincelam em camadas os discursos, na paráfrase ou na polissemia, em toda gama material discursiva em que o sujeito se posiciona e confronta o sistema e seus representantes. Essa disputa em jogo está localizada em regiões de poder, domínios de poder, materializados nas divisões dos morros pelo tráfico, pelas facções, e pelo que tivemos acesso das representações desses movimentos sociais no narcotráfico, pelo que Althusser ([1970] 1980) nomeou de aparelhos ideológicos do Estado, e que Pêcheux ([1975] 1988) retomou para falar sobre a luta de classes e legitimação de sentidos.

A tensa disputa pela tomada de palavra fornece a ilusão tanto do sujeito ser, quanto do sujeito ter, a saber: o saber. O ser e o ter são transmissíveis por meio da identificação ao nome, item trabalhado por Pêcheux ([1975] 1988, p. 101) em Semântica e Discurso, e que constitui uma evidência primordial: "[...] é evidente que somente 'eu' poderia dizer 'eu' ao falar de mim mesmo". Porém, relembrando, o sujeito é um efeito ideológico, uma posição no discurso (que muda de lugar, é errante, desliza, é dividido), um portador de um saber que ele não con/tém (que é parcial, local, datado, fragmentado, circula), e/ou ainda, ele não é nada, pois é furo, é nonsense, é um impossível sujeito (Bairrão, 2003) e só ganha corpo se re/presentado por um significante a outro significante (Lacan, [1964] 1998). Ainda em Pêcheux ([1975] 1988), p. 102), encontramos: "Concluiremos esta primeira aproximação do problema do pré-construído destacando, como uma sua característica essencial, a separação fundamental entre o pensamento e o objeto do pensamento". E se a situação do contexto não está definida a priori, temos que, para a $\mathrm{AD}$, os sentidos também não são estanques, são re-construídos e podem sempre ser outros, pois " $[. .$.$] as palavras, expressões, proposi-$ ções, etc., mudam de sentido segundo as posições sustentadas por aqueles que as empregam, o que quer dizer que elas adquirem seu sentido em referência a estas posições, isto é, em referência às formações ideológicas [...] nas quais estas posições se inscrevem" (Pêcheux, [1975] 1988, p. 160). Dessa forma, as formações discursivas dentro de determinadas formações ideológicas seriam determinadas pelas lutas de classes, que determinam o que pode/deve ser dito em determinada produção discursiva em um momento específico.

Para tanto, selecionamos para este trabalho um corpus composto de recortes do documentário Falcão - Meninos do Tráfico (Athayde \& Bill, 2006a), do livro fruto do documentário - com o mesmo título (Athayde \& Bill, 2006b) -, e de recortes das pesquisas de Dowdney (2003) e Feffermann (2006), analisados com maior apuro em nossa dissertação de mestrado. Cada material nos proporcionou o acesso a alguns discursos dos envolvidos no contexto do narcotráfico e as gerações fruto desse meio de vida. Assim, o documentário Falcão (Athayde \& Bill, 2006a), a partir de um ângulo mais unilateral, colocou em foco as vozes dos agentes da "firma" que trabalham nela, mas não são os grandes beneficiados pelo retorno que o tráfico de drogas proporciona. A pesquisa de Dowdney (2003) colabora tanto com 
a história da entrada e expansão do narcotráfico no Rio de Janeiro, por meio de entrevistas com moradores, ex-traficantes, crianças e jovens do narcotráfico, quanto por meio de entrevistas com representantes da polícia, e segue rumo aos demais responsáveis pela situação: os governantes e o poder público. Já Feffermann (2006) vai falar sobre sua pesquisa de campo em São Paulo capital, fazendo análises sobre o social e sobre a subjetividade desses jovens, com intervenções baseadas em Adorno, Horkheimer e Freud, e dando voz a esses jovens que traficam.

Com todos os cuidados em abranger da forma mais ampla possível o material selecionado o contexto, os personagens envolvidos, a história sobre o narcotráfico no Brasil -, ainda assim cairemos fatalmente na parcialidade, por uma série de limitações que abrangem de forma constitutiva a pesquisa em si, tais como a dificuldade de formalizar dados paralelos que não puderam fazer parte de nossa dissertação, por conta da riqueza e abundância de material selecionado nas referidas pesquisas. Também cabe destacar que as pesquisadoras, enquanto seres de linguagem - já que a linguagem fatalmente nos coloca como sujeitos castrados (no sentido psicanalítico do termo) - têm a possibilidade de traçar uma pesquisa, e não todas as outras que, simultaneamente, deixaram de fazer. É impossível falar tudo sobre tudo: ao dizer $\mathrm{x}$, simultaneamente estamos deixando de dizer y, z, etc. São recortes de recortes, de material previamente selecionado; porém, isso não diminui o trabalho e o valor de analistas do discurso, que estão por base comprometidos com elementos que fluem em qualquer discurso, em qualquer lugar em que haja enunciação, e se debruçam para fazer ecoar repetições, ambiguidades, cortes, lapsos, condensação, deslocamento, metáforas e metonímias, na busca de novos sentidos e novas questões.

O imperativo das condições materiais dos filhos e netos do tráfico faz-se presente por uma soma de negativas, que denuncia a miséria material de moradores das favelas, em um contexto de falta absoluta de boas condições de moradia, até mesmo pelo processo de autourbanização em que foram construídas as moradias nos morros e nas periferias. Esse processo é decorrente do êxodo rural do começo do século passado, e entre as suas causas destaca-se a falta de alimentação, de educação, de permanência na escola, de acesso aos bens culturais - tais como cinema, teatro, artes em geral, apresentações musicais diversificadas. Todos esses elementos compõem uma malha linguageira que irá abraçar o sujeito daquele lugar, capturar o sujeito em uma ficção agressiva, e subjetivar as crianças nesse lugar em que não só as faltas, mas também os excessos visam ao corpo, pela violência, pelos abusos, com as gírias, entoando em coro uma paráfrase, com propagação de genéricos. Um contexto em que crianças são usadas como bucha de canhão - corpos atirados, ignorados, usados, numa regularidade de sentidos que retroalimentam a menos valia, num ambiente em que uma simbolização fica bem limitada, comprometida, já que a fantasia é podada com os explícitos, os espaços para produção simbólica quase que inexistem, e o que pulsa escapa no corpo que padece, que é morto, consome droga e é por ela consumido. Nas palavras de Kehl (2006, p. 1):

O que sobra a estas crianças para fantasiar se a onipotência, motor da fantasia infantil, se realiza todos os dias na forma da tirania praticada por seus irmãos mais velhos, tios e pais adolescentes destinados a morrer antes dos vinte anos? Do ponto de vista da constituição psíquica, a fantasia é o suporte do desejo. Fundamenta a experiência da interioridade, de um "si mesmo" que mede sua diferença em relação ao mundo real. Uma subjetividade sem fantasia é uma terra devastada, sujeita a servir ao gozo do Outro.

O impossível de dizer diferente é consequência da naturalização, que intercambia o poder, o poder-a-menos, que implica um sujeito poder dizer a menos, inscrito numa posição sócio-histórica e, ainda que em frangalhos, em um desejo. Não conseguimos delimitar onde termina um e começa o outro, mas talvez possamos aferir que, se as necessidades muitas vezes embasam a entrada no narcotráfico, seria da ordem do desejo/gozo o que sustenta a permanência nele. Isso porque a mudança de lugar pode parecer impossível ao sujeito assolado por suas condições, quaisquer que sejam elas, e quaisquer que sejam os sujeitos.

É característico do ser humano experimentar em algum momento da vida, ou vários, a sensação de impotência, de não haver outros caminhos, não haver outras possibilidades de dizer e de se dizer; porém, ao longo da história sempre houve aqueles sujeitos que deslizam pelos sentidos dados como legítimos pela ideologia dominante, furam o sistema imposto, desafiam os contornos que a norma social 
desenha delimitando os destinos alheios - aqueles que conseguiram romper com políticas que não os representavam. Consideramos que é esse o caso das tantas crianças e famílias que conseguem não se envolver diretamente com o narcotráfico, dos policiais que se negam a ser cúmplices de colegas corruptos e sádicos que aparecem atrelados às políticas e ações de combate ao tráfico, e daquelas pessoas que, apesar de terem sido violentadas por membros do tráfico, perdido entes queridos, não deram continuidade à roda de extermínio ligada pelo ódio, vingança, desconfiança - por terem feito outra opção em suas vidas (Zaluar, 2006).

\section{Uma entrada histórica e a naturalização ideológica: o narcotráfico não existiu sempre}

Inicialmente, abordaremos um fio da história do narcotráfico no Rio de Janeiro, importante polo de funcionamento e de fundamento das atividades comerciais que movimentam cerca de 400 bilhões de dólares anualmente em todo o mundo (Feffermann, 2006, p. 25), além de envolver níveis altíssimos de violência armada. Focaremos os lugares que foram surgindo e sendo ocupados, aos poucos, por crianças, de acordo com uma ampla pesquisa de campo desenvolvida por Dowdney entre 2001 e 2002. Nessa pesquisa, ele trabalhou com entrevistados entre 12 e 23 anos de idade, sendo que, "os com mais de 17 anos foram escolhidos para as entrevistas por terem começado a trabalhar no tráfico quando crianças ou menores" (Dowdney, 2003, p. 19).

Com a gravidade do problema posto em xeque com as denúncias feitas por pesquisadores como Dowdney (2003), Feffermann (2006), Athayde, Bill e Soares (2005), Kehl (2006), de documentadores e críticos como Athayde e Bill (2006b), Angeli (2005a, 2005b), e em trabalhos de mídias como Revista Época online (Brum, 2006), Revista Fantástico (A odisséia Falcão, 2006), jornal Folha de São Paulo (Zaluar, 2006; Kehl, 2006), dentre tantas outras, observamos como esse tema cortante envolve não só os trâmites da ilegalidade, mas a insuficiência da legalidade - representada na voz do Estado e do governo - para assegurar uma outra forma de organização social que dê suporte para essas crianças poderem crescer e se subjetivar em uma sociedade que de fato as proteja e lhes ofereça outros modelos que não estes a que elas estão expostas cotidianamente. Os dados midiáticos analisados colocam em causa as seguintes questões: como são faladas essas crianças que fazem parte da terceira, quarta geração de traficantes de entorpecentes do Brasil? De que modo os adultos discursivizam tais meninos? Em que lugar estamos, quando discutimos a generalização ou o desaparecimento da infância hoje? Dentre tantas outras questões, estas indicam esse espaço de interseção que borra os limites entre o ser criança e o ser adulto, em que os lugares sociais ocupados por cada um possibilita(va)m ver o que chamaremos de infantil. Os personagens são múltiplos: as crianças, sua família, a comunidade à qual pertencem, as facções, os traficantes, o Estado e seus representantes, a mídia, os pesquisadores, e, também, nós, autores e leitores desta pesquisa. Somos todos parte de um efeito de geopolítica do tráfico de entorpecentes, que confirma seus "padrões históricos de dependência e distribuição desigual da riqueza nas relações" entre as classes dominantes e as classes dominadas.

Não estamos propondo a (re)tomada de um posicionamento político partidário nem uma divisão igualitária das produções materiais e dos discursos, já que, segundo a teoria discursiva, atentamos para o postulado de que a heterogeneidade é constitutiva do sujeito, dos sentidos e da linguagem. Estamos, sim, atentando para alguns efeitos que são historicamente demonstrados nas lutas de classes e de regiões de poder, nos dogmas, nas crenças autoritárias, no apagamento do outro, na ignorância do que não convém aos poderosos, no silenciamento dos portadores de pouca ou nenhuma condição de viver com dignidade de um ser humano, demonstrados em diversos atos históricos. Não precisamos retomar os fatos e efeitos devastadores vivenciados em Auschwitz, Vietnã, as atrocidades das Grandes Guerras Mundiais, e bem recentemente, a imposição da ditadura militar por vinte anos no Brasil dos anos 1960, as guerras religiosas e civis do Oriente Médio (em andamento), o genocídio na Faixa de Gaza, só para citarmos algumas delas, que afeta(ra) $\mathrm{m}$ as gerações que se seguiram. Precisamos (tentar) compreender como o tráfico recruta os meninos e meninas para uma prática que, diferentemente das guerras citadas anteriormente, não é discursivizada com o efeito de massacre.

Como o tráfico de drogas não é enquadrado dentro das grandes guerras civis, até por sua constância, que faz dele um protótipo da sociedade 
de consumo, a maneira com que se lida com ele também tendeu a uma conformidade, uma apatia social (Cárdia, 1998), uma naturalização pelo efeito ideológico de evidência de que toda a violência expressa por ele e embutida nele produz ainda mais violência. É como se isso fosse algo sem tratamento, sem possibilidades de mudanças e, portanto, faz-se assim e ponto. Porém, sabemos que o tráfico não existiu sempre, muito menos com a forma que tem hoje, com suas proporções, com sua organização, corporificando-se como um fenômeno político-econômico-social "aceito" enquanto possível. Ele foi construído em uma história cheia de vírgulas, parágrafos, espaços, hiâncias, hiatos, sujeitos, objetos, substantivos, adjetivos, e ainda é reticente. Sua representabilidade naquelas três instâncias (político-econômico-social) é inegável, é um fenômeno imensurável a que só temos acesso em partes, com uma leitura crítica. "Somente por meio da crítica o pensamento eria capaz de recuperar a potência especulativa que lhe é próprio, libertando-se, assim, do obscurecimento causado pelo tecnicismo" (Feffermann, 2006, p. 16). No sentido etimológico, "crítica vem de uma palavra grega, krinein, que quer dizer quebrar". A mesma palavra está na raiz de crise, por exemplo (Nestrovski, 2005, p. 10).

Assim, tentaremos inscrever uma crise e uma crítica em nosso discurso, desnaturalizando sentidos que confortavelmente são tidos como aceitos e mostrando algumas das mudanças ocorridas na estruturação do narcotráfico. Buscamos desconfiar da transparência e das aparências para quebrar a suposta naturalidade empregada ao status quo do narcotráfico brasileiro e da inserção de crianças nesse meio de trabalho, e preservar a tensão (atenção) necessária ao estranhamento.

Apesar das mudanças radicais da natureza entre os traficantes e moradores, tais como são percebidas por estes últimos, a dominação das comunidades pelas facções só tem sido possível por ser baseada, historicamente, em estruturas existentes de controle social e de proteção (Dowdney, 2003, p. 40).

Há que se considerar ainda as transformações sociais decorrentes dos avanços tecnológicos e do próprio capitalismo, com sua oferta de felicidade avaliada pelo consumo e pelo mercado, num processo de fetichização e glamourização que podem iludir o sujeito em sua condição de existência - uma ilusão de tamponamento e de completude, de gozo, de pseudoideais, todos fadados ao fracasso que, por sua vez, será o motor do comércio de drogas altamente lucrativo para alguns. O fracasso da felicidade para o sujeito capitalista é a insatisfação que o coloca em com/pulsão para o consumo, qualquer que seja o objeto desejado.

Assim, na segunda metade do século 20, as drogas assumem uma condição estratégica, pois com as condições históricas de um mundo quase inteiramente cientificizado, o desamparo do sujeito atinge proporções insuportáveis (Feffermann, 2006, p. 26).

Contudo, o tráfico (s)urge em resposta ao real que coloca o sujeito diante de uma impossibilidade de um outro dizer, ou, dito de outra forma, de uma outra inscrição no dizer, que fica marcado na história daqueles que encontram a miséria em questão, uma questão de necessidades. (S)urge também em contraponto, em resposta gozosa a uma falta que é estrutural, mas que vai trabalhar não na via do desejo, mas na via de um gozo, de um poder gozar, como é o caso de alguns droga/dictos, que fazem falar o dizer da droga/dicção.

Nós tem pouco estudo. Se bate, tem até uns amigo que nunca estudou. Então pra nós trabalhar é foda. Tá ligado que eles discrimina nós à vera (verdade) mesmo. Então nosso único recurso é recorrer a isso aí, à boca de fumo, tá ligado? Pra nós sobreviver, sustentar nossa familia (Athayde \& Bill, 2006a, Doc. 01, jovem traficante, 19'27').

Qualquer que seja o chamado avanço social, tecnológico e científico, o que o sujeito busca é um reconhecimento, e sua pulsão, visa à satisfação, ensina-nos a psicanálise, e os meios que ele se utilizará para esse fim são os mais variáveis possíveis - estes, sim, poderão deixar rastros nas esferas sociais em que se estabelecem as relações de poder. $\mathrm{Na}$ recapitulação histórica feita em sua pesquisa, Dowdney (2003) revela que as mudanças estruturais ocorridas no seio do narcotráfico se deram de forma processual, constituindo os atuais efeitos de sentidos partindo de um período cronológico em que a criança era vista de outra forma pelos traficantes, pela comunidade, 
pela polícia. A constante falta do Estado, por intermédio de seus representantes políticos, foi um dos componentes fundamentais para que os "donos" assegurassem seus lugares e fossem experimentando e estabelecendo as leis dos territórios que dominam. Aqueles que abriram a possibilidade da inserção da criança no tráfico de drogas ilegais foram os primeiros traficantes do final de 1970 e começo da década de 1980, dentre eles, o ex-traficante "Meio quilo", que foi um famoso "dono" dos anos 1980 no Rio de Janeiro, e um dos primeiros a empregar crianças nesse meio:

Eu posso até tá enganado em dizer que ele foi o primeiro, mas que ele foi um dos pioneiros a usar isso como arma, a presença da criança como arma, porque eu já vi várias vezes o policial deixar de atirar porque era uma criança [...] hoje em dia não tem mais isso, até porque a criança já perdeu aquela aura de que, pô, "é só uma criança eu não vou atirar nela”, [agora é] "vou atirar mais" porque os ossos não são tão bem definidos e o corpo é mais delgado, é mais flexível, e o metabolismo da criança é mais acelerado, então "eu tenho que atirar pra matar, mas se eu não atirar pra matar ele vai continuar vivo e vai atirar em mim". Agora atiram pra matar. Como eles tentaram atirar pra matar em mim por exemplo. Te falei, né, eu levei um tiro aqui, na altura dessa costela aqui (Ex-traficante dos anos 1980 apud Dowdney, 2003, p. 166).

Aqui podemos nos perguntar se a questão feita pelo pesquisador ao ex-traficante já não colocaria a criança como sendo usada como arma, o que não seria um problema, mas um aspecto da pesquisa de Dowdney (2003, p. 15), que faz mesmo um paralelo entre as crianças do tráfico e crianças-soldado. As primeiras, ainda não reconhecidas internacionalmente em sua grave situação, por serem categorizadas como "delinquentes juvenis, criminosos ou membros de quadrilhas", e as segundas, reconhecidas e, por isso, protegidas legal e internacionalmente como "crianças-soldado", tratadas como soldados, com autorização legal para agirem como soldados dentro de período determinado que, passado, dada a natureza excepcional da situação, permitiria que a vida deles voltasse ao normal. Dowdney (2003, p. 13) propõe uma nova delimitação categórica para as crianças do tráfico: que sejam reconhecidas como "crianças em violência armada organizada", que abarca não só as crianças e jovens que participaram de sua pesquisa, mas reflete uma nova categoria que não é exclusiva das favelas do Rio de Janeiro e que constitui um corpus internacional de nossa aldeia denominada global.

Além disso, no recorte anterior, há indícios dessa desvalorização e revalorização da criança que foi usada como arma, como "isso" ("usar isso como arma, a presença da criança como arma"), que "perdeu aquela aura" de que criança era só uma criança e passou a ser vista como um corpo mais delgado, de metabolismo mais acelerado, flexível, o que resulta no cálculo: tenho que matá-la antes que ela me mate ("o corpo é mais delgado, é mais flexível, e o metabolismo da criança é mais acelerado, então "eu tenho que atirar pra matar, mas se eu não atirar pra matar ele vai continuar vivo e vai atirar em mim". Agora atiram pra matar. Como eles tentaram atirar pra matar em mim por exemplo. Te falei, né, eu levei um tiro aqui, na altura dessa costela aqui').

Observamos, aqui, o retorno dos efeitos de morte de crianças já dados pela memória discursiva, quando elas eram passíveis de extermínio, de serem usadas na guerra, na tortura e em mutilações. Notamos, ainda, na sequência desse dizer, um deslocamento que a criança sofre na particularização desse dizer pessoal - ela é nomeada de "ele", já que eles atiraram nesse ex-traficante. E os dados das pesquisas selecionadas cruzam-se nessa fala, apontando para a grande maioria de meninos que trabalham no narcotráfico, assim como o gênero de seus parentes: "quarenta por cento dos entrevistados declararam ter parentes empregados no tráfico, sempre do sexo masculino, pais, irmãos, primos, tios..." (Dowdney, 2003 , p. 20). Em outro recorte, o sujeito discursiviza a dinâmica de valorização da criança a serviço do tráfico:

[Meio-quilo] queria evitar a todo custo a perda de soldados e especialmente crianças, elas eram valiosíssimas para ele. Primeiro porque não ficavam presas, segundo porque as presas escapavam (nota de rodapé 60) [...]a criança era mais rápida, a criança corria mais, mais ágil, era menor, passava entre buraco dentro da favela [...] a criança era meio macaco mesmo, era usada que nem um macaquinho[...] e uma visão mesmo utilitária da coisa, o menor de idade, mesmo carregando uma arma pesada, ele 
consegue correr mais rápido do que o adulto [...] por ser pequena, se meter nos buracos e fugir com a arma, e não perder o armamento (Ex-traficante dos anos 1980 apud Dowdney, 2003, p. 167).

Essa mentalidade se reflete também na instituição policial, sustentando suas estratégias, justificando suas ações, relacionadas diretamente ao aumento de mortes no Rio entre 1993 e 2001, e que, de acordo com um major da Polícia Militar, que explicou o seguinte aos pesquisadores de Dowdney (2003, p. 172):

O potencial ofensivo de uma criança ou de um adolescente com uma arma de fogo é muito superior ao de um adulto armado. [...] Em razão do nível de maturidade da criança ou do adolescente, [...] a possibilidade do adulto atirar no policial é muito menor do que criança ou adolescente atirar.

$\mathrm{Na}$ voz de um garoto que se enuncia como um menor, sua história no tráfico emerge pela transferência com seu fiel, que lhe serve de figura de proteção contra os que o "esculacharam" e que depois dele "começar a andar" com os "bandido", "afrouxaram", ele é quem lhe dá um reconhecimento e dinheiro, quem fortalece e que dá a possibilidade de um futuro no social ilegal: ele sonha em ser bandido. Os sentidos de força ("fortalece"), que ele não tem enquanto menor, enquanto aquele que não tem tamanho, deslizam para o sentido capitalista, em que o forte é aquele que tem dinheiro.

MV: Teu fiel é bandido?

Menino: É

MV: Você gosta de andar com bandido?

Menino: Gosto. Por que como? Porque muitas pessoa gostam de esculachar os menor, tá ligado? Mas quando a gente começa a andar com os bandido, começa na vida do crime, eles vão tudo afrouxar pra cima dos menor.

MV: O que você quer ser quando crescer? Menino: Quero ser bandido.

MV: Essas pessoas com quem você anda, que você diz que são bandidos, elas fazem o que de bem pra você?

Menino: Eles dão dinheiro, fortalece (ajuda) à vera (verdade) aí.
MV: E você faz o que em troca?

Menino: Em troca eles pede pra fazer alguma coisa, tipo como? Comprar lanche, comprar gasolina pras moto. Eu vou lá e faço.

MV: Quem é seu maior ídolo hoje?

Menino: Como assim?

MV: Quem é a pessoa adulta que você mais gosta?

Menino: Que eu mais gosto? Do meu fiel. Do meu fiel, pô.

(Athayde \& Bill, 2006a, Doc. 01, voz de criança, 20'04").

Os pesquisadores citados até aqui observaram que o processo de recrutamento é voluntário, seguido da naturalização da convivência com traficantes (que muitas vezes são seus parentes) e até mesmo pelo afeto por eles, como enunciado no recorte anterior. Os pesquisadores notaram que as crianças não eram procuradas pelas facções do tráfico e observaram, também, que a infância é vista pelos traficantes e pelas crianças que trabalham no tráfico de uma forma bem particular: elas são avaliadas pela capacidade (o "preparo") de exercer a função, produzir, e não pelo critério de idade. Um depoimento de 2006, do documentário Falcão nos fornece cenas de um discurso que sustenta a categoria nomeada por Dowdney (2003), em que o jovem está inserido na "violência armada organizada" de forma crônica, naturalizada, como ele diz: "me acordaram dormindo"

Celso: Já foi preso?

Falcão: Já fui preso duas vezes. Saí há pouco tempo agora, semana retrasada, sexta-feira. Maior sofrimento ter que andar com a mão pra trás, comida péssima, parece até lavagem. A gente é visto como um animal, não como ser humano. Solitária, pô, muito sinistro, solitária, sozinho, não pode falar nada, tem que ficar no silêncio, se os caras escutar você falando uma coisinha, eles já vêm pra quebrar, já vem e te tira, quebra, tapa na cara, esculacho, tapa na cara, madeirada, tudo isso (Athayde \& Bill, 2006b, p. 79- 80).

A reciprocidade forçada entre policiais e traficantes é também estabelecida entre traficantes e comunidade - não há democracia, há o que Dowdney (2003, p. 57) chama por "narcoditadura". O sistema 
carcerário é também um parceiro mudo e surdo, cúmplice dos criminosos na medida em que os cala, impedindo-os de fazerem uma elaboração simbólica sobre seus atos, seus efeitos, suas consequências, quem são; dessa forma, denuncia o agravamento do problema social calando seus presos, sustentando-os, enclausurando-os e violentando-os fisicamente. Ambos agem no corpo e calam as palavras. Porém, entra pra firma quem procura, busca e pede com palavras para entrar, com seriedade, com "firmeza na conversa", como disse um dos jovens em um dos recortes selecionados.

As facções aceitam as crianças e adolescentes que optam por entrar no tráfico não só por aquela noção de infância descrita em outro recorte, mas também porque muitos gerentes de boca (pontos de venda), também entraram quando criança. Em geral, são menores de idade (que não se identificam como tal, nem identificam os outros desse modo), pois se considera que as crianças são mais competentes para várias funções no tráfico, custam menos na remuneração do serviço, além de ficarem menos tempo presas, caso a polícia as detenha. Segue um recorte que ilustra isso:

$\mathrm{T}$ - Ah, se a criança ou algum menor quiser vir... a gente não deixa entrar no tráfico. A gente não deixa. A gente não deixa. Por isso que ninguém pede pra entrar.

E - Mas eu já conversei com vários menores que trabalham no tráfico, que deixaram que entrassem.

$\mathrm{T}$ - Menor sim... de certa idade... aqueles menor. A gente fala os... já tá mais adulto, é isso que eu quero dizer, os já mais adulto...

E - O que que é uma criança então pra você?

Até que idade?

T - Poxa, até os 14 anos.

E - Até os 14 anos é uma criança.

T - 14 já tá... pra cima, já sabe...

E - Já sabe o que?

T - É, de 13, né... pra baixo ainda é criança.

E - Então, de 13 pra cima, é... já era, é adulto.

$\mathrm{T}$ - É. Quem a gente considera os mais adultos, os que já... a gente já sente mais confiança... os que já levam... a gente já sente mais firmeza na conversa, no papo.

E - Você achava que, quando você tinha 14 anos e você entrou no crime, você era criança? T - Não! Eu não me achava mais criança.
(Gerente de preto, 23 anos) (Dowdney, 2003, p. 131).

Os já/mais adultos representam aqui a grande maioria que morre no narcotráfico - não chegam nunca, jamais, à fase adulta, perpetuam os sentidos caros ao capitalismo: eficientes, capazes, eficazes, produtivos, têm firmeza na conversa, no papo, porém escamoteiam-se em suas condições de crianças, sua infância, são jovens que se posicionam como se fossem falcões, olheiros, vapores, fiéis, mas se esquecem de que estão num jogo dialético, são eles também que estão na mira, que podem “evaporar”, que são infiéis consigo mesmos. Realizar a onipotência de poder pelo viés do discurso totalitário do narcotráfico é apagar as fantasias que poderiam rumar o desejo a se ancorar em outros discursos possíveis, é quebrar as asas alçando o voo do falcão, é findar o corpo na droga/dicção e a carne na terra antes de completar a maioridade. O lema das facções e seu principal objetivo é o progresso econômico e, em nome dele, são aceitas as crianças que se comprometem com seriedade a entrar na ciranda do tráfico e trabalhar duro, seguindo ordens e cumprindo pactos.

Em contraponto, há as crianças que não procuram pelo tráfico, que não buscam a solução nas facções, mas que convivem em suas realidades com o esquema dos morros. Pesquisas apontam para efeitos nefastos que os conflitos gerados no embate entre traficantes e policiais causam em outras crianças, aquelas que resistem a naturalizar a violência cotidiana: "Junto a crianças pequenas, a violência crônica tem impacto inclusive fisiológico [...] afeta seu desenvolvimento emocional. Esse estresse se evidencia na forma de uma síndrome pós-traumática que se reflete em especial sobre o desempenho escolar das crianças e dos adolescentes" (Cárdia, 1998, p. 142). Para essas crianças, a permanência do conflito é tão perturbadora que médicos que as examinavam consideravam a situação como sendo pior que as guerras declaradas - nessas crianças foram sequenciados diversos, como ansiedade, irritação, menor capacidade de concentração, pânico, tremedeiras, diarreias, fobias. Há também relatos de outros sintomas graves que bloqueiam a capacidade da criança de explorar o mundo à sua volta, de construir uma autoestima, autonomia, autoconfiança, etc. (New USP apud Cárdia, 1998). A noção de tempo também é afetada, impedindo o desenvolvimento do planejamento a longo prazo - a vida fica por um fio 
a todo tempo. Essa condição é vivida por todo ser humano, sujeito à morte inesperadamente; porém, isso fica em um plano secundário, não vivemos com esse pensamento o tempo todo, ele fica recalcado apesar de sabermos desse traço inerente à condição humana. No entanto, nessa fase de desenvolvimento, as crianças deparam-se repetidamente com a questão, produzindo uma estranha síntese: ou naturaliza-se a violência, ou surge o sintomal.

\section{O tráfico e suas leis em análises discursivas: (a)firma discursiviza o polissêmico}

"O dono prensa a voz, a voz resulta um prato Que gira para todos nós (...)

A voz foi infiel, trocando de traquéia

E o dono foi perdendo a voz" (A voz. do dono e o dono da voz, Chico Buarque)

A afirmação da firma é de tal legitimidade, que é frequente a associação entre crime/narcotráfico e profissão, assim como possibilita a polissemia do "pensar legal" como um pensamento na legalidade, e também no sentido de um pensamento bem elaborado, reflexivo, legal, como observamos no recorte anterior. Também a segurança é um quesito importante, que depende do "tanto" a ser pago aos policiais, estabelecendo fronteiras e permitindo o movimento da firma, abrindo a fronteira para o que "vem de fora", fazendo a conversão da carga (a droga) em dinheiro, no mercado que se estabelece na "pista", como observamos nos recortes a seguir.

Trabalhar também sem RH, segurança, não dá, porque senão eles te zoam...Que que acontece? Nós oferece tanto a eles pra eles deixar nós trabalhar em paz, e eles ganhar o deles lá e nós ir movimentando a firma pra levantar o nosso dinheiro, irmão. (Athayde \& Bill, 2006a, Doc. $\left.01,10 ’ 28^{\prime \prime}\right)$.

Pô, isso aqui é a carga... Carga? Pô, carga é os "pó" da boca que movimenta a firma. Movimenta a firma, faz dinheiro pra firma (Athayde \& Bill, 2006a,Doc. 01, jovem, 03'51").

Dentro do contexto do narcotráfico nas comunidades das grandes cidades, que servem de modelo de funcionamento e organização também para cidades menores, tanto pela generalização de gírias e formas de organização (Athayde, Bill \& Soares, 2005) quanto pela estrutura interna do comércio de entorpecentes, a firma funciona por/como uma rede de "atores afiliados independentes (donos), que garantem apoio mútuo para fins defensivos ou ofensivos" (Dowdney, 2003, p. 41). Essa organização compõe uma estrutura hierárquica com finalidade de ganho financeiro e de poder, ou a/firma/ção social, sendo bem demarcados os papéis e as funções de cada um na realização desse objetivo primordial, desde a etapa de receber até a etapa final de endolar, que é distribuir a carga no varejo e o retorno da venda em dinheiro (ou objetos de interesse dos traficantes).

A hierarquia possibilita certo movimento, já que a ascensão social em seu interior se faz tanto pela necessidade das facções por causa das baixas de mão de obra (mortes dos traficantes mais antigos), quanto pela demonstração de qualidades e capacidades de se exercer determinada função por parte de novos interessados (Dowdney, 2003; Feffermann, 2006). O processo de recrutamento voluntário acontece desde cedo, por volta dos oito anos de idade, de forma "natural", "já que as crianças são expostas ao tráfico desde muito cedo na comunidade, e aqueles que têm interesse começam "andando" com traficantes, e entram para trabalhar em tempo integral no tráfico entre os 10 e 15 anos" (Dowdney, 2003, p. 143). Mas a naturalização do processo às vezes é questionada e suspendida enquanto único destino possível para um sujeito, como verificamos no posicionamento de um sujeito, na voz de uma viúva de um jovem traficante (que foi assassinado aos 17 anos e deixou um filho com essa jovem):

Porque os outro diz: "ah, corre no sangue". Não corre no sangue, não. Entra se quiser. Eu deixo bem explicado. E quando o meu filho crescer eu vou querer falar o que o pai dele foi, como o pai dele era. E vou falar pra ele: "se tu acha que isso é o certo e quiser seguir o que o teu pai seguiu, o caminho é esse daí, é a morte" (Athayde \& Bill, 2006a, Doc. 02, 22'46").

O que corre no sangue é material genético, isso que circula na pulsação social não é mais natural, orgânico, biológico, é fruto da cultura, é da ordem do humano e, portanto, da linguagem. Essa mãe coloca uma hiância entre o que "os outro diz" heterogeneidade mostrada - e o que ela fala e vai falar, 
demarca um querer, um "se", aposta em um momento de escolha que seu filho, como um sujeito, terá que fazer: "Não corre no sangue, não" - discurso indireto. O problema é ignorar o assujeitamento, a interpelação, as sucessivas identificações com os personagens do narcotráfico, a forma como esse querer racional se confunde com a captura do sujeito naquele discurso em que seu pai se filiou e o levou à morte, um querer que está sujeito a regras inconscientes, sob a operação ideológica e pelo próprio funcionamento do inconsciente. Essa mãe propõe o questionamento, o que é de vital importância para suspender a naturalidade das coisas que os circundam e quebrar a repetição que tende a se instalar.

Contudo, as questões de ordem primária (alimentação, moradia, saneamento básico, saúde, educação, etc.) falam mais alto nas condições que fazem o trilho para que a criança ou o jovem busquem o narcotráfico, pois a seriação de menos em suas rotinas, de descaso do governo, e da oferta que o narcotráfico faz, conjuntamente levam a consequências paradoxais: efeitos na ilusão de tudo poder e/ou de nada poder. Na primeira, ou seja, na ilusão de tudo poder, é como se a violência não doesse, ficasse anestesiada, escamoteada, silenciada, e, nessa repetição ou seriação de dores causadas pela violência, o sujeito a naturaliza como forma de defesa e sai da segunda ilusão, a de nada poder: ele desliza para a ilusão de potência, ele aguenta tudo, pode tudo, faz tudo, nada teme. Mas lembramos que isso é uma ilusão, uma crença, que muitas vezes leva à morte desses sujeitos. Na segunda ilusão - a de nada poder -, a ferida está sempre aberta, a cicatriz constantemente sendo arrancada, o nada pode fazer emergir um "fazer em si os sintomas", que são metáforas da dor no corpo que sofre:

Eu não sou bandido não. Eu tô aqui porque eu preciso, certo? Ajudar dentro de casa, porque eu não quero ver minha coroa sofrendo. Então, pô, quer comprar um gás, o gás já é trinta e poucos real.... A gente tá nessa luta aí, se os home chega aqui nós vai ser tratado como bandido. Se bater, mete bala em nós, mata geral, nem leva de dura (Athayde \& Bill, 2006a, Doc. 01, 20’02”).

E se eu não tiver aqui, tá ligado? Ninguém vai correr atrás, tá ligado? Então eu não vou ter um futuro, eu não vou ter é nada, tá ligado?
Essa vida é sem futuro por um lado, tá ligado? Mas pelo menos aqui eu tô ganhando meu pão, mano, tô sendo mais bem tratado do que estando largado, tá ligado? (Athayde \& Bill, 2006a, Doc. 01, 19’47’).

"Não corre no sangue não", "Eu não sou bandido não", "[...] eu não vou ter um futuro, eu não vou ter é nada" constituem uma estrutura sintática que funciona no discurso na forma denegativa, como que escamoteando aquilo que é possível, mas logo negado em seu próprio discurso e de modo a pedir a repetição do não, do nada, do né. "Tá ligado" é uma gíria que está presente em grande parte dos depoimentos, o que se liga é algum objeto, a convergência do humano em coisificação, em maquinário de produção, que a qualquer momento pode ser "largado", não ter futuro. No primeiro recorte, os sentidos de "bater", "meter", "matar" fazem retornar os sentidos dessas vidas que não contam, não têm valor, que precisam lutar contra o sistema e seus representantes, os policiais, para sobreviver, e que esse é "um lado" da questão da vida, senão ele não vai ter um futuro, não vai ter é nada. O futuro aqui é no presente, "não vou ter é nada", também é negado, barrado, destituído do vir-a-ser. O jovem nega ser bandido, mas sabe que será tratado como tal, mesmo com sua motivação voltada ao sustento familiar, ajudar em casa, fortalecer, etc. Aliás, a marca "mas" é outro indício do funcionamento discursivo da denegação, em que a figura da mãe é muitas vezes usada como justificativa para as atividades ilícitas do narcotráfico:

Por mês eu faço uns... Sem mentira, no tráfico eu faço uns 500. Eu trafico, mais pela minha mãe. Porque eu sei que minha mãe não gosta. Mas trafico pra sustentar minha mãe (Athayde \& Bill, 2006a, Doc. 02, 09’50”).

Pô, vou fazer 18 anos, já tô crescendo. Pô, minha mãe já fez tudo por mim. A gente tem que fazer por ela agora, né? Agora que ela tá passando da idade, a gente tem que fazer por ela. A gente sabe que é errado, mas a gente tem que fazer alguma coisa. Não tem um trabalho pra gente arrumar, entendeu? A gente tem que viver nessa condição de entrar na vida do crime (Athayde \& Bill, 2006a, Doc. 02, 10'04'). 
Meu pai não fortalecia nada. Minha coroa passava mal comigo. Aí deu a maior revolta mesmo, entrei pra essa vida mesmo, boladão. Como? Tô aí até hoje. Fortaleço minha coroa, fortaleço minha família (Athayde \& Bill, 2006a, Doc. 02, 09'34').

MV: E você tem que idade?

Jovem: Eu tenho 17.

MV: E o que você ganha é o suficiente?

Jovem: É.

MV: Quanto é que você ganha?

Jovem: $\mathrm{R} \$ 350,00$

MV: E qual a carga horária que você trabalha? Jovem:De meio-dia até às 06:00 (da madrugada) MV: Você fazia o quê?

Jovem: Eu era crente, da Igreja Universal... Depois, quando meu pai meteu o pé (foi embora), depois que minha mãe morreu, minha tia começou a me disvi...desprezar. Eu falei, o jeito é o tráfico de drogas. Sete anos na vida do crime (Athayde \& Bill, 2006a, Doc. 02, 10'49”).

O crack prejudica tudo. Mas é da onde... Dele que nós ganha dinheiro, né, mano? Dele que nós ganha dinheiro (Athayde \& Bill, 2006a, Doc. 01, jovem, 5'23').

As crianças começam "andando" com os traficantes, comprando lanches, levando recados, e logo passam a ser nomeadas a ocupar os lugares na organização, de olheiro, vapor, gerente de boca, soldado, fiel (impar), gerente geral, dono; e todos podem crescer na hierarquia (Dowdney, 2003). $\mathrm{E}$ as marcas denegativas se repetem nas vozes dos meninos que estão no narcotráfico, nos clamando interpretação: "senão", "né", "não dorme", "não dorme à noite", "Falcão não dorme, não", como observamos a seguir:

Ficar olhando sempre pra ver eles primeiro, nunca deixar eles me ver, senão eles vai me matar. Tenho que ver eles primeiro. Vou deixar eles chegar de pertinho dali? Não pode (Athayde \& Bill, 2006a, Doc. 01, Falcão, 06’41”).

Falcão é o jovem que vigia e toma conta da favela (Athayde \& Bill, 2006a, Doc. 01, voz de MV Bill, 02'54"').
Falcão pra mim significa que, que tá no tráfico noturno, né? Não dorme, parece que, parece um passarinho, que não dorme à noite (Athayde $\&$ Bill, 2006a, Doc. 01, jovem, 03'04').

Falcão não dorme, não. Ele descansa. Ele descansa que ninguém é de ferro. Ele tem que descansar. Ou então quem já é viciado, já dá-lhe uma e fica na onda dele (Athayde \& Bill, 2006a , Doc. 01, jovem, 07’07”).

Vapor é, geralmente são os menores de idade que vendem a droga no varejo (Athayde $\&$ Bill, 2006a, Doc. 01, 03'42').

Contenção também é conhecido como fogueteiro, é o jovem que avisa da chegada da polícia ou de possíveis inimigos também (Athayde \& Bill, 2006a , Doc. 01, MV Bill, 05’53”).

Com relação ao manejo da droga, existe o matuto, que é uma figura geralmente misteriosa, que traz a droga do exterior para os morros e circula entre vários "donos" - uma vez dentro do tráfico, ela circula nas mãos de outros "funcionários". Dowdney (2003) insiste na ênfase do papel desses dois elementos-cabeça do tráfico: o dono e o matuto, pois temos mais acesso às aparências, aos agentes que aparecem, principalmente na mídia televisiva, que são os olheiros, falcões, soldados, fiéis, etc, enquanto os arquitetos do plano de estruturação e funcionamento do varejo estão num plano de fundo, muitas vezes inacessíveis, ocultos, e são justamente quem mais faturam com a "firma" e os maiores responsáveis conjuntamente ao Estado (quando omisso, ausente, ineficaz) e aos consumidores (que são o mercado, a justificativa de toda a sustentação da firma, são os agentes na demanda pelo produto e que pagam por isso que demandam e desejam consumir). Enquanto prestamos atenção aos "testas-de-ferro", aos "laranjas", às "abelhas menores", operárias do sistema, crianças, jovens e policiais, estamos deixando de saber das cabeças que estão nas duas extremidades jogando com seus funcionários-soldados, autorizando e aliciando: Estado e os "donos":

MV: Quem traz?

Jovem: Tem tipo assim, umas pessoas pra trazer aí... Aí ela vem, tipo de fora, chega na 
favela, nós leva o quilo pra embalação, embala tudo e já bota na pista pra vender.... Como tá vendo aí, sou um cara que nem era pra estar aqui (Athayde \& Bill, 2006a, Doc. 01, 17'13").

Tem o cortador, tem o que desfaz a maconha, e tem o que amarra e pesa, entendeu? (Athayde \& Bill, 2006a, Doc. 01, jovem, 18’10”).

Para além das questões de ordem de necessidade, das condições de miséria, dos menos com menos $\left(-+_{-}=+\right)$, a criança e o jovem encontram no tráfico um reconhecimento representado por um nome com o qual o sujeito se identifica, um lugar simbólico que supõe um reconhecimento perante o social, ganha um crédito que averigua sua importância, no avesso do menos (-), ele ganha um "mais" $(+)$ : o nome de um cargo/função dentro da firma e um nome-apelido que o particulariza dentro daquele grupo. Eé assim que aterrorizam o social, se tornam o perigo que ameaça a sociedade, que por sua vez tentará puni-los de toda forma, consentindo às práticas de extermínio, se calando perante o caos social, ficando apática com os noticiários que denunciam tantas violências com essas crianças, inclusive fechando os olhos para as práticas policiais, que são um fragmento das práticas ideológicas governamentais (executiva, legislativa e jurídica). O discurso inscrito até aqui alimenta e é nutrido pela ciranda de matar ou morrer, o que cria um efeito de futuro limitante ou mesmo impossível - ele não aparece como algo do vir-a-ser, ele é tomado em sua presentificação no agora. Assim, o futuro se torna o agora, o presente. $E$ isso parece tudo nas vozes que se seguem, já que o destino é previamente determinado ou, no máximo, indica dúvida e incerteza: "Meu futuro? Meu futuro é três... é, igual todo mundo fala. É três caminho: é cadeira de roda, ou morte ou cadeia" (Athayde \& Bill, 2006a, Doc. 03, 05'13"').

"É igual todo mundo fala", esse sujeito fala na homogeneidade, ele se apaga em subjetividade, o que o alçaria a ser sujeito no singular, em suas particularidades, com possibilidades de descontinuar esse dito gozoso e imperativo do "somos todos iguais", ou ainda, aqui, "É igual todo mundo fala". Quem fala? Como ele se deixa determinar, ou, em outras palavras, como ele é assujeitado? Sabemos, por Pêcheux ([1975] 1988), que a interpelação ideológica é o que possibilita a construção de um discurso tomado como naturalizado, óbvio, impossível de ser diferente por ser socialmente instituído. Porém, e ainda de acordo com o mesmo autor, o sujeito "sendo 'sempre-já' sujeito, sempre-já se esqueceu das determinações que oconstituem como tal" (Pêcheux [1975] 1988,p. 170), pois é um ser de linguagem que foi falado antes de poder falar, e foi se inscrevendo-identificando a determinadas formações discursivas (matriz de sentidos) ao longo de sua história (Leandro-Ferreira, 2006).

Ainda sobre os imperativos capitalistas, tomados como dizeres impressos na mídia e na contínua pressão sobre o sujeito para que este consuma/ seja consumido, não interessando quem são esses sujeitos (se são crianças, adolescentes, ou adultos), observamos que o que impera é o apagamento do sujeito, que paga muitas vezes com seu ser para poder gozar. Um sujeito a/pagado tem sua subjetividade a/pagada "no que ela se mostra, no que se esconde, no que é repetição ou equívoco, no que se marca como diferença, no que se inscreve enquanto homogeneidade" (Leandro-Ferreira, 2006, p. 33). De acordo com a autora:

Em resumo, a subjetividade [...] resulta do acontecimento da linguagem no sujeito. Um acontecimento que tanto possibilita a singularização da diferença quanto a regulação do sujeito relativamente a uma universal adaptação do sujeito à ordem cultural e social através do mesmo simbólico que o constituiu (LeandroFerreira, 2006, p. 33).

O gozo é representado na glamourização do narcotráfico, quando analisamos os dizeres daqueles que respondem narrando o fascínio que as armas causam neles mesmos e nas meninas que eles conquistam ao serem portadores dessas armas, ou desses lugares que ocupam em uma facção, seu status na comunidade, descrevendo o prazer da adrenalina que as "batalhas provocam", no mimetismo das músicas, vestes, gestos, e clipes, que refletem os rappers americanos.

\section{Consideraçóes finais}

Um aspecto importante que descobrimos com a pesquisa, e que almejamos que alcance efeitos que contribuam na desconstrução de sentidos estanques para a sociedade de sentidos homogêneos, é quanto ao surgimento e estabilização do narcotráfico, 
que não existiu sempre. $O$ narcotráfico tem uma história que o constituiu, e que se assegura com o tripé produção-tráfico-mercado em uma polissemia de lugares - sua dissolução demanda ações em cada setor desse tripé, ou seja, com vistas à droga, à logística que funciona de forma internacional, e, principalmente, com vistas aos consumidores, que fazem da droga um dos grandes sintomas do mal- estar da civilização moderna. A heterogeneidade constitutiva da linguagem encontra um eixo subjetivo no ser criança nessa convivência com o narcotráfico, que por sua vez também é fruto histórico dos acontecimentos, pois a criança não existiu sempre, não esteve sempre no narcotráfico, não foi sempre utilizada para o progresso econômico ou para o gozo capitalista que dita: consuma e se consuma. Há crianças que naturalizam essas formações discursivas, se identificando com o narcotráfico que, além de lhe prover o necessário, lhe confere um lugar simbólico, um lugar de reconhecimento, mas antes de falarem, alguém já por elas falou sobre elas, e isto deixa efeitos para o sujeito. Por outro lado, há aquelas que não naturalizam o "fora-da-lei", a violência que acompanha essas condições de produção dos dizeres e que, portanto, somatizam, sofrem, vivem em conflito com tantas faltas de garantias de sua sobrevivência e de dignidade para viverem com suas famílias. Enquanto os governantes, a esfera acadêmica, a mídia, e a população em geral não se darem as mãos em parcerias, em estranhamentos para com esses acontecimentos, o sintomal continuará a prevalecer com a forma da droga/dicção, mancando de forma a levar a civilização para a morte, expressa nos números ligados ao narcotráfico mundial. E o que é pior, que envolve a cada dia mais crianças nessa realidade.

\section{Referências}

Angeli. (2005a). Corpo de delito. Folha de S. Paulo, São Paulo, 13 maio, p. A-2.

Angeli. (2005b). Da Febem para o presídio. Folha de S. Paulo, São Paulo, 16 mar., p. A-2.

Althusser, L. (1980). Ideologia e aparelhos ideológicos de Estado (Notas para uma investigação). Tradução de Joaquim José de Moura Ramos. Lisboa: Editorial Presença. (Originalmente publicado em 1970).
A odisséia Falcão. (2006). Fantástico: O show da vida em revista, 1(1), 130-135.

Athayde, C., \& Bill, M. V. (2006a). Documentário Falcão: Meninos do tráfico [Áudio e vídeo gravados do Programa Fantástico da Rede Globo de televisão]. Rio de Janeiro: Globo.

Athayde, C., \& Bill, M. V. (2006b). Falcão: Meninos do tráfico. Rio de Janeiro: Objetiva.

Athayde, C., \& Bill, M. V., \& Soares, L. E. (2005). Cabeça de porco. Rio de Janeiro: Objetiva.

Cárdia, N. (1998). Introdução: Reduzindo a mortalidade infantil e aumentando os homicídios de jovens. In P. S. Pinheiro et al. São Paulo sem medo: Um diagnóstico da violência urbana. Rio de Janeiro: Garamond.

Dowdney, L. (2003). Crianças do tráfico: Um estudo de caso de crianças em violência armada organizada no Rio de Janeiro. Rio de Janeiro: 7 Letras.

Feffermann, M. (2006). Vidas arriscadas: O cotidiano dos jovens trabalhadores do tráfico. Petrópolis: Vozes.

Khel, M. R. (2006). As asas quebradas. In Observatório da imprensa. Recuperado em 5 maio 2009, em http:/ / observatorio.ultimosegundo.ig.com.br/ artigos.asp?cod $=374 \mathrm{ASP} 002$

Lacan, J. (1998). O seminário, livro 11: Os quatro conceitos fundamentais da psicanálise. Rio de Janeiro: Jorge Zahar. (Originalmente publicado em 1964).

Melo Neto, J. C. de (2001). Uma faca só lâmina ou serventia das idéias fixas. In Moriconi, I. (Org.). Os cem melhores poemas brasileiros do século. Rio de Janeiro: Objetiva.

Nestrovski, A. R. (2005). Notas Musicais: Do barroco ao jazz. São Paulo: Publifolha.

Orlandi, E. P. (1987). A linguagem e seu funcionamento: As formas do discurso. 2. ed. Campinas: Pontes.

Pêcheux, M. (1988). Semântica e discurso: Uma crítica à afirmação do óbvio. Tradução de Eni P. Orlandi. Campinas: Editora da Unicamp. (Originalmente publicado em 1975). 
Pêcheux, M. (1990). Análise automática do discurso. In: F. Gadet, \& T. Hak (Orgs.). Por uma análise automática do discurso: Uma introdução à obras de Michel Pêcheux (pp. 61-161). Campinas: Editora da Unicamp.

Zaluar, A. (2006). Falcão, o documentário. In Observatório da imprensa. Recuperado em 5 maio 2009, em: http:/ /observatorio.ultimosegundo.ig.com. br/artigos.asp?cod=374ASP002 $\mathrm{T}$

Recebido: 10/01/2010

Received: 01/10/2010

Aprovado: 21/04/2010

Approved: 04/21/2010 